\title{
PEMBENTUKAN LAPISAN MUTIARA BLISTER Pteria penguin DALAM SEMBILAN BULAN PERKEMBANGAN
}

\author{
(Blister Pearl Layer Formation of Pteria penguin in Nine Months Development)
}

\author{
Yanti Kaleb $^{1^{\star}}$, N. Gustaf F. Mamangkey ${ }^{1}$, Desy M. H. Mantiri ${ }^{1}$ \\ 1. Program Studi Ilmu Kelautan, Fakultas Perikanan dan IImu Kelautan, Universitas Sam \\ Ratulangi, Manado \\ *e-mail : yanti.antik@gmail.com
}

The study was conducted with aims to analyze the development of layer thickness of blister (mabé) pearl and to compare it with the layer thickness of the shell during the period of nine months. The study was carried out in Arakan, District of Minahasa Selatan and then continued in laboratory analysis. The molluscs used in this study were inserted and glued with plastic nuclei in their internal part of their shells. Sampling was conducted in $3^{\text {rd }}$, $5^{\text {th }}$ and $9^{\text {th }}$ month after insertion. Blister pearl formed was cut transversely to observe the development of pearl layers. The result of this study revealed that pearl development increased on $3^{\text {rd }}, 5^{\text {th }}$ and $9^{\text {th }}$ month by $25.26 \mu \mathrm{m}, 46.12 \mu \mathrm{m}, 47.18 \mu \mathrm{m}$, respectively.

Keywords: Pteria penguin, blister pearl, mabé pearl, pearl thickness

Penelitian ini dilakukan dengan tujuan untuk menganalisis tingkat perkembangan pada ketebalan lapisan mutiara jenis blister mabé dan perbandingan ketebalan lapisan cangkang dengan lapisan mutiara selama kurun waktu sembilan bulan. Penelitian dilakukan di perairan Arakan, Kabupaten Minahasa Selatan dan dilanjutkan dengan analisis di laboratorium. Kerang disisip inti plastik pada dinding bagian dalam. Sampling dilakukan pada bulan ke-3, 5 dan 9 . Bagian yang terbentuk blister kemudian dipotong secara melintang untuk melihat perkembangan lapisan. Berdasarkan hasil penelitian ini maka didapatkan bahwa perkembangan ketebalan lapisan mutiara meningkat ukuran rata-rata lapisannya pada bulan ketiga $25.26 \mu \mathrm{m}$, bulan kelima $46.12 \mu \mathrm{m}$ dan bulan kesembilan $47.18 \mu \mathrm{m}$.

Kata kunci: Pteria penguin, Mutiara mabé, mutiara blister, Tebal Mutiara

\section{PENDAHULUAN}

Kerang Pteria penguin atau 'winged pearl oyster' adalah salah satu jenis kerang mutiara yang termasuk genus Pteria dalam filum Mollusca (Wada \& Tëmkin, 2008), dan juga disebut kerang bercangkang kupu-kupu (Strack, 2006). Masyarakat lokal khususnya daerah Arakan, Sulawesi Utara menyebutkan kerang ini adalah kerang garuda. Habitat kerang Pteria penguin berada pada zona litoral dan sublitoral. Distribusi Pteria penguin tersebar di Indo-Pasifik.

Produksi mutiara dapat dibagi menjadi dua jenis yaitu mutiara alami dan mutiara budidaya. Mutiara alami terbentuk berdasarkan hasil reaksi tubuh karena adanya luka pada jaringan dalam mantel moluska dengan menghasilkan material untuk melindungi jaringan tubuh di sekitar luka tersebut (Taylor dan Strack, 2008). Mutiara yang dibudidaya terbentuk secara alami tetapi sebelumnya disisipi inti mutiara dan potongan mantel dari kerang donor yang dibantu oleh manusia (Taylor \& Strack, 2008). Namun kerang yang biasa dipakai dalam menghasilkan mutiara secara massal adalah genera Pinctada dan Pteria (Pinctada margararitifera, Pinctada maxima, Pinctada fucata dan Pteria Penguin) (Strack, 2006; Gervis \& Sims, 1992; Mamangkey, 2009). Khusus Pteria penguin, kerang jenis ini berpotensi menghasilkan mutiara setengah atau mutiara blister (mabé) (Strack, 2006 dan Wada \& Tëmkin, 2008). 
Terdapat tiga lapisan struktur mutiara (Fougerouse et al., 2008) yaitu: (1). Periostrakum luar yang sebagian besar terdiri dari protein; (2). ostrakum medial atau lapisan prismatik, terdiri dari kristal kalsit dalam matriks organik; dan (3). hipostrakum dalam atau lapisan nakre ('mother of pearl'), yang terdiri dari kristal aragonite dalam matriks organik. Struktur utama dalam pembentukan nakre terbentuk dari proses mineralisasi (Adaddi et al., 2006). Nakre dikenal juga 'mother of pearl' (MOP) merupakan lapisan yang membentuk struktur dinding bata tiga dimensi dimana mortar dari lapisan tipis biopolimer (20-30 nm) dan $95 \%$ aragonite $(\mathrm{CaCO} 3)$ (Barthelat \& Espinosa, 2007).

Informasi ilmiah khususnya yang berhubungan dengan deskripsi penebalan lapisan mutiara jenis blister (mabé) pada Pteria penguin di perairan ini atau di Sulawesi Utara secara umum masih minim. Jadi diperlukan studi untuk mengetahui penebalan lapisan, pembentuk lapisan mutiara pada Pteria penguin karena mengingat potensi sumberdaya dari kerang jenis ini sebagai penghasil mutiara.

\section{METODE PENELITIAN}

Lokasi penelitian berada pada daerah pesisir dan laut di Desa Arakan, Kabupaten Minahasa Selatan, Sulawesi Utara dan Laboratorium Biologi Kelautan, Fakultas Perikanan dan IImu Kelautan, Universitas Sam Ratulangi. Kegiatan pengambilan dan pengukuran sampel dilakukan di Desa Arakan dan analisis ketebalan mutiara di Laboratorium Biologi Kelautan. Penelitian ini dilakukan selama sepuluh bulan.

Prosedur kerja di lapangan disajikan Gambar 1. Kegiatan penelitian diawali dengan penyiapan alat dan bahan yang digunakan dalam menunjang penelitian ini. Kemudian, pada setiap kegiatan monitoring dan sampling dalam pengambilan data kerang dilakukan persiapan alat dan bahan sebelum pergi untuk melakukan kegiatan monitoring dan sampling. Pengambilan sampel kerang di Arakan Kecamatan Tatapaan Kabupaten Minahasa Selatan dilakukan dengan bantuan para nelayan di kawasan laguna di depan desa.

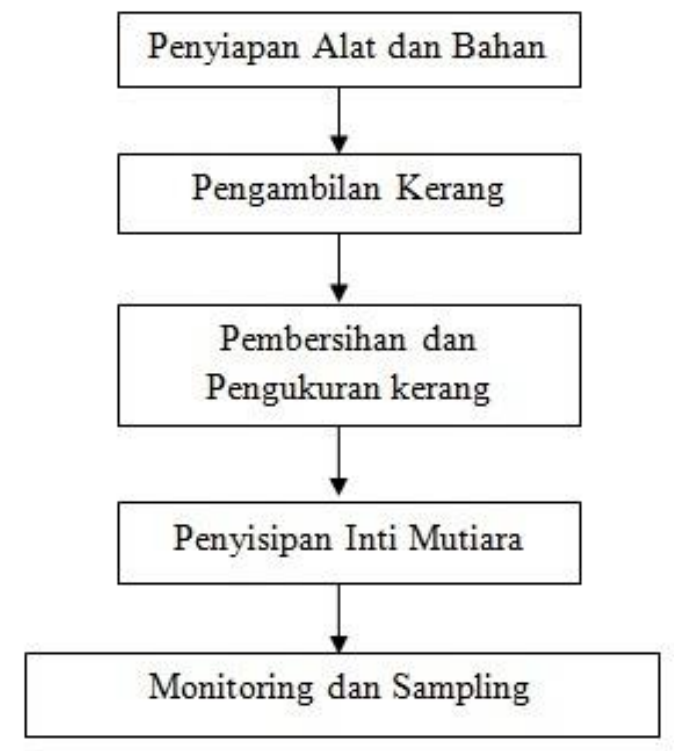

Gambar 1. Prosedur kerja di lapangan

Pengambilan kerang dilakukan dengan mengambil kerang Pteria penguin yang menempel namun bisus kerang tersebut dipotong tidak ditarik dari subsratnya. Jumlah kerang yang digunakan sebanyak 6 kerang. Pengambilan sampel kerang dilakukan pada bulan ketiga, kelima dan kesembilan. Setelah pengambilan, kerang Pteria penguin dibersihkan dengan menggunakan sikat, pisau dempul, gunting dan tangan mengunakan dengan memakai sarung tangan. Pembersihan kerang dimaksudkan untuk mengangkat biota pengotor yang menempel di cangkang bagian luar. Setelah kerang bersih, kerang diukur tinggi, lebar dan tebal cangkang dengan menggunakan jangka sorong dengan ketelitian sampai $0,5 \mathrm{~cm}$. Sedangkan berat kerang diukur dengan menggunakan timbangan digital dengan ketelitian sampai 1 gram. Setelah dilakukan prosedur kerja pembersihan pada kerang Pteria 
penguin. Kerang yang sudah bersih dilakukan penyisipan inti mutiara. Penyisipan inti mutiara dilakukan dengan menunggu kerang sampai terbuka kemudian ditahan mengunakan baji. Setelah itu, dengan ditahan kedua cangkang kerang dengan pembuka cangkang, kerang Pteria penguin disisipi inti mutiara berbahan plastik dan berbentuk setengah bulat yang sudah diberi lem anti air. Inti mutiara dilekatkan antara mantel cangkang pada bagian dalam cangkang. Jumlah inti mutiara yang disisipkan adalah 2 3 biji berbahan plastik. Kerang yang sudah disisipi inti mutiara kemudian diberi label. Selanjutnya, kerang dimasukan ke dalam 'pocket net' yang sudah diberi kabel tis kemudian dibawa ke laut menggunakan perahu dan digantung pada jaring 'long-line'. Monitoring dan sampling terhadap mutiara dilakukan bersamaan selama sembilan bulan. Pada saat monitoring kerang di bersihkan dan diukur morfometri. Pengukuran morfometri tubuh cangkang yang berjumlah enam individu kerang Pteria penguin mencakup tinggi, lebar, tebal dan berat. Pengambilan kerang Pteria penguin menggunakan perahu yang tergantung sebelumnya di 'long-line'. Label kerang diperiksa kembali, jika tidak ada labelnya hilang maka akan diganti dengan label yang baru. Pada pengambilan atau sampling kerang pada bulan ketiga berjumlah satu, bulan kelima sampling satu kerang dan pada bulan kesembilan di sampling empat kerang. Setelah melakukan sampling pada setiap bulan pengambilan, maka dilakukan pemotongan inti mutiara. Pemotongan kerang dilakukan dengan cara memotong bagian samping mutiara sehingga berbentuk setengah bulat. Setelah itu, mutiara dibelah dua secara simetris dengan memotong mutiara tersebut secara vertikal menggunakan alat pemotong seperti Gambar 2 . Prosedur obervasi untuk analisis dilakukan penyiapan lapisan mutiara dan lapisan cangkang dilakukan dengan menggunakan Stereo Microscope yang diperlengkapi dengan Camera Lucida

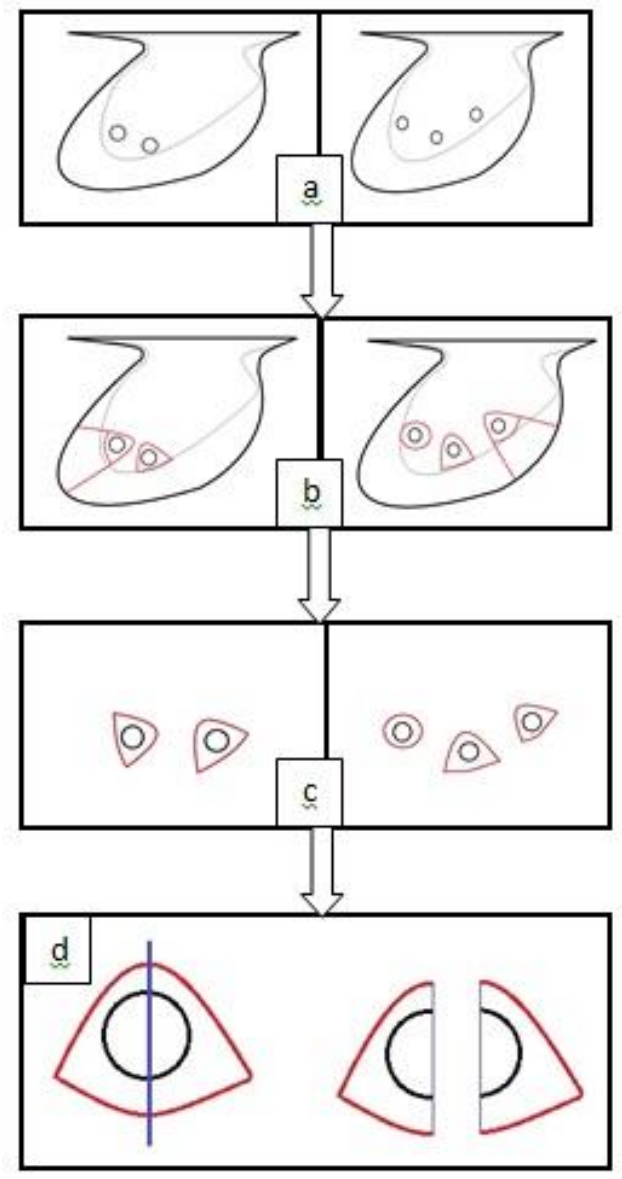

Gambar 2. Bagan alir pemotongan mutiara dari cangkang (garis merah): cangkang yang di dalamnya ada mutiara mabé (a), pemotongan mutiara mabé dari cangkang (b), mutiara mabé yang sudah di pisahkan dari cangkang (c) dan pembelahan mutiara mabé yang dibelah dua (d)

\section{Analisis Data}

Setelah dilakukan pengukuran karakter morfometri (tinggi, lebar, tebal dan berat) data dianalisis dengan 


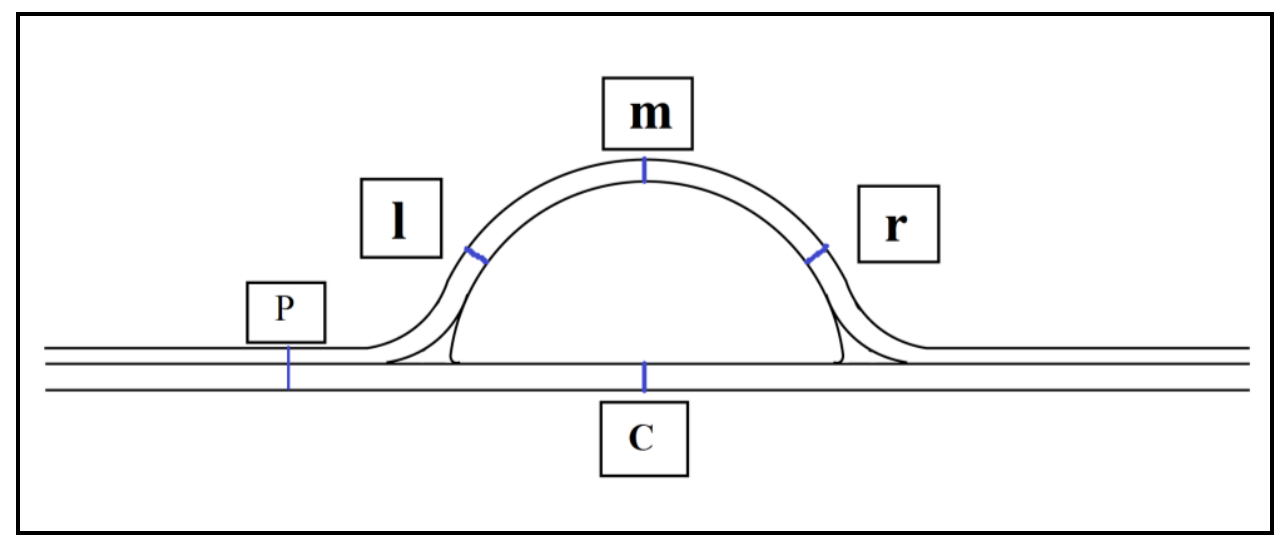

Gambar 3. Pengukuran lapisan mutiara dan lapisan kerang : kiri (I), tengah $(\mathrm{m})$, kanan ( $r$ ), ketebalan lapisan cangkang bagian tengah inti $(C)$ dan ketebalan cangkang sampai cangkang $(P)$

menggunakan Microsoft Excel. Hasil rata-rata tinggi, lebar, tebal dan berat kerang setiap bulan disajikan dalam bentuk grafik dan dianalisis dengan menggunakan ANOVA (add-ins dari Microsoft Excel) untuk mengetahui signifikan tidaknya perbedaan parameter morfologi yang diukur.

\section{Ketebalan Lapisan Mutiara dan Perbandingan Ketebalan Cangkang dengan Lapisan Mutiara.}

Analisis ketebalan lapisan mutiara dilakukan dengan menghitung rata-rata dari bagian lapisan mutiara yang di ukur (kiri, tengah dan kanan) (Gambar 3). Lapisan cangkang yang telah terbentuk bersamaan dengan lapisan mutiara (P) serta lapisan cangkang awal (C) (sebelum ditempelkan inti mutiara) diukur. Nilai $\mathrm{P}$ dikurangi nilai $\mathrm{C}$ diambil sebagai tebal lapisan cangkang. Kemudian tebal lapisan mutiara ( $\mathrm{l}, \mathrm{m}$, dan $\mathrm{r}$ ) juga diukur dan diambil rata-ratanya sebagai representasi tebal lapisan mutiara. Perbandingan ketebalan lapisan mutiara dan lapisan cangkang kerang, lapisan cangkang dikurang dengan ketebalan lapisan mutiara. Kemudian hasilnya diolah di Microsoft Excel lalu disajikan dalam tabel dan grafik.

\section{HASIL DAN PEMBAHASAN}

Hasil data pengukuran morfometri tubuh kerang Pteria penguin yang digunakan dalam penelitian ini berjumlah 6 individu kerang. Ukuran rata-rata $( \pm \mathrm{SD})$ tinggi kerang pada Bulan I $18.83 \mathrm{~cm}$ (3.98), Bulan III 18.16 $\mathrm{cm}$ (2.80), Bulan V $18.4 \mathrm{~cm}$ (2.77) dan Bulan IX $19.62 \mathrm{~cm}$ (2.56) ; lebar kerang pada bulan Bulan I $9.91 \mathrm{~cm}$ (1.71), Bulan III $9.83 \mathrm{~cm}$ (1.50), Bulan V 10.2 cm (1.48) dan Bulan IX $10.5 \mathrm{~cm}$ (1.47) ; dan tebal kerang bulan Bulan I $4.25 \mathrm{~cm}$ (1.03), Bulan III $3.91 \mathrm{~cm}$ (0.66), Bulan V $4 \mathrm{~cm}$ (0.61) dan Bulan IX $4.62 \mathrm{~cm}$ (0.25). Selanjutnya, hasil pengukuran rata-rata berat kerang ( $\pm S D)$, pada bulan Bulan I $259.17 \mathrm{~g}$ (156.33), Bulan III $285 \mathrm{~g}$ (78.56), Bulan V $298.8 \mathrm{~g}$ (77.03) dan Bulan IX $361.25 \mathrm{~g}$ (55.79).

Berdasarkan hasil Analisis Keragaman (ANOVA, Single Factor), F hitung pada tinggi kerang 0.19052431 dimana memiliki nilai lebih kecil dari $\mathrm{F}$ 'crit'= 3196777; pada lebar cangkang kerang $\mathrm{F}$ Hit $0.17835306<\mathrm{F}$ 'crit' 3.196777; tebal cangkang kerang $F$ 'crit' yaitu: $0.484048<3.196777$ dan berat cangkang kerang nilai $F$ hitung adalah 0.669947 dan lebih kecil dari $F$ 'crit', 3.196777. Oleh sebab itu dari ketiga parameter yang diukur (tinggi, lebar dan tebal berat) tidak berbeda secara signifikan walaupun terjadi perkembangan. Berdasarkan hasil analisis pengukuran morfologi tubuh 
kerang Pteria penguin, kerang Pteria penguin telah memasuki tahap dewasa sehingga perkembangan tinggi, lebar, tebal dan berat tidak signifikan akan

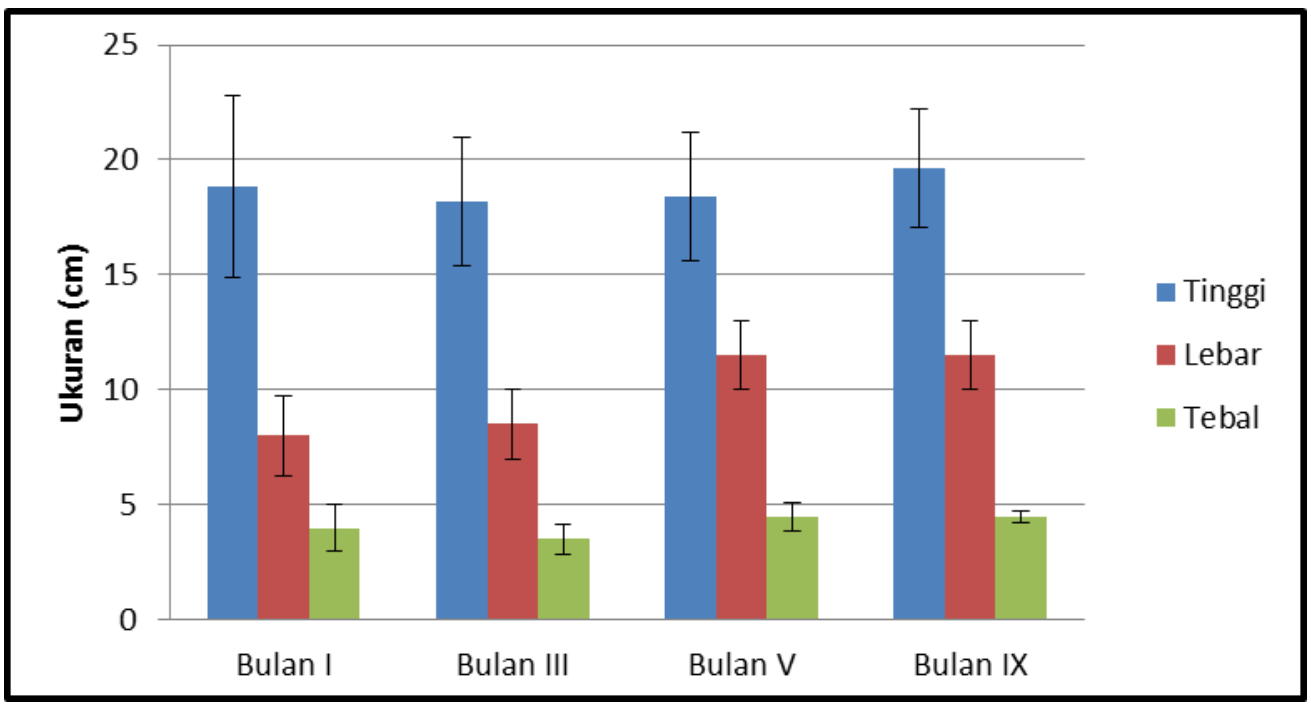

Gambar 4. Grafik pengukuran morfometri tinggi, lebar, dan tebal cangkang kerang (rata-rata \pm SD)

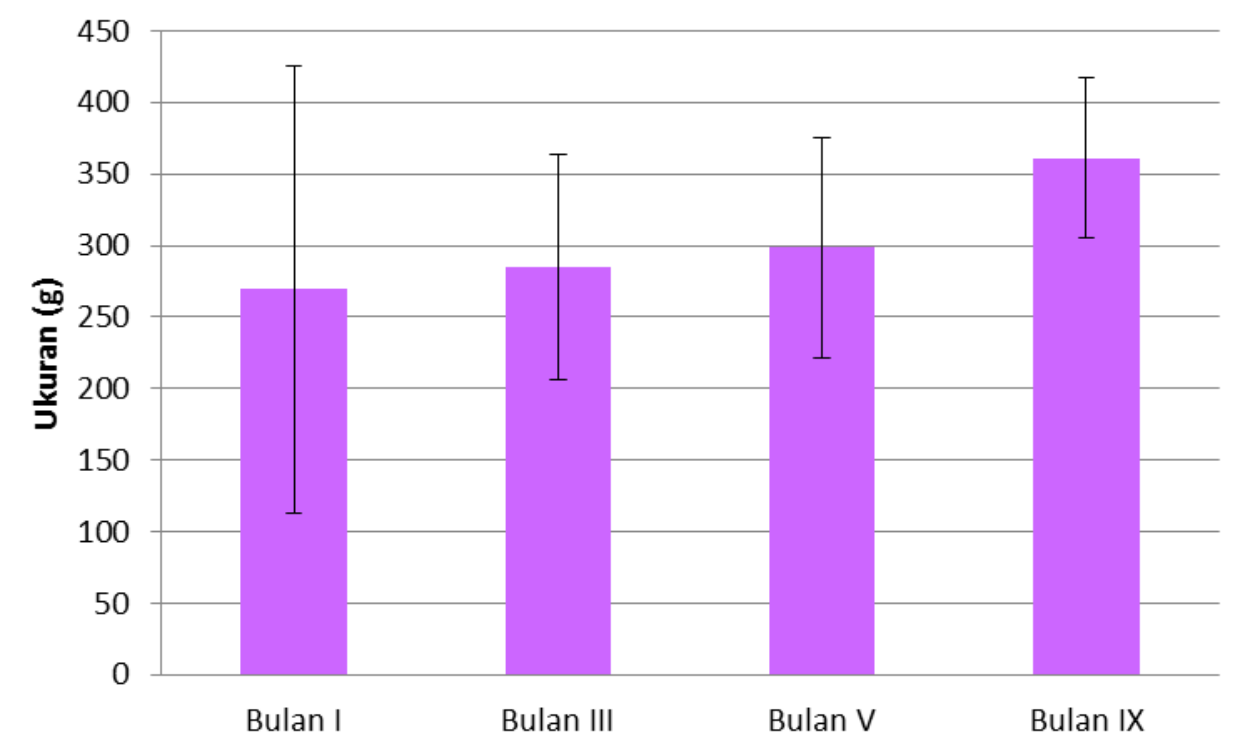

Gambar 5. Grafik pengukuran berat kerang (rata-rata \pm SD)

tetapi mengalami pertumbuhan. Kerang ini mendekati pertumbuhan maksimal, lapisan cangkang akan menebal di kearah bagian dalam dan di samping itu perkembangan bagian internal lebih membesar terutama pada saat matang gonad (Almeida, et al., 1997). Menurut Hamzah dan Nababan (2009), penurunan ukuran mutiara disebabkan oleh kulit cangkang mutiara tersebut ditumbuhi oleh 'biofoling' yang lambat laun akan rusak dan mengurangi laju pertumbuhan, bila tidak cepat dibersihkan akan menjadi kerdil. Biofouling mempengaruhi perkembangan kerang mutiara $P$. margaritifera karena biota lain yang menempel pada kerang (Lacoste et al., 2014). 


\section{Ketebalan Lapisan Mutiara Blister Dan Perbandingan Ketebalan Lapisan Cangkang dengan Lapisan Mutiara Pteria Penguin}

Tatapaan, Kabupaten Minahasa Selatan didapatkan bahwa pada bagian dalam cangkang yang terlihat saat cangkang terbuka bagian di area nakre berwarna-warni yaitu kuning, keemasan, hijau, perak dan pink. Selanjutnya, di samping batas nakre atau bagian tengah putih mengkilat atau perak. Bagian ventral cangkang berwarna hitam. Hasil observasi dari bagian dalam cangkang memiliki kesamaan warna pada bagian nakre adalah berwarna-warni, warna keemasan, perak, abu-abu dan pink. Menurut Strack (2006) Warna nakre adalah pink bercahaya, pink kebirubiruan, pink gelap da nada yang mempunyai warna keemasan-metalik sampai abu-abu dan hitam. Sedangkan menurut Wada \& Tëmkin (2008), Warna bagian nakre adalah berwarna-warni yang berkilau, perak, dan pink.

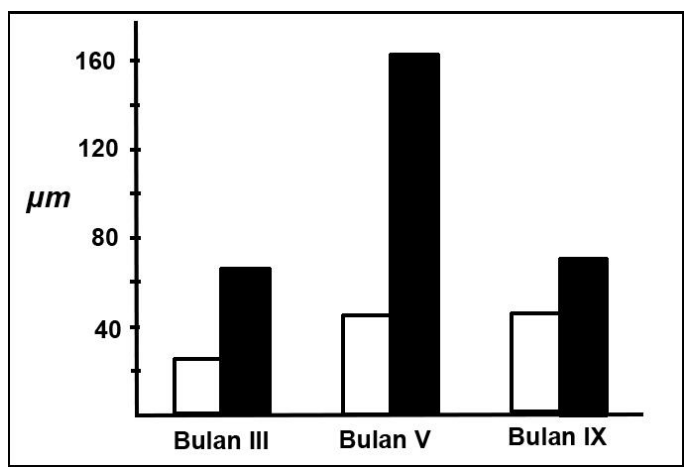

Gambar 6. Grafik perbandingan ketebalan rata-rata lapisan mutiara blister (mabé) pada Pteria penguin (putih) dan pengukuran ketebalan lapisan cangkang (hitam) pada Pteria penguin

Hasil dari monitoring dan sampiling mutiara dilihat keberhasilan implementasi inti yang ditempelkan dalam cangkang kerang. Dalam pengamatan visual menunjukkan
Observasi visual morfologi kerang Pteria penguin yang dilakukan penelitian di desa Arakan, Kecamatan

perkembangan pelapisan lapisan mutiara pada inti mutiara. Monitoring dan sampling mutiara pada bulan pertama, pada inti yang satu berwarna cokelat membungkus inti yang ditempelkan bagian internal atau dalam tubuh kerang dapat diketahui

merupakan lapisan periostrakum sudah membentuk di inti mutiara berbahan plastic. Lapisan periostrakum yang dieksresikan dari sel-sel epitel dari kelenjar periostrakal sebagai lapisan yang relatif tipis yang terdiri dari protein kuinon kecokelatan (asconchiolin) (Fougerouse et al., 2008; Gervis and Sims, 1992 dan Chi-Miau dan Watabe, 1989). Moluska menggunakan lapisan periostrakum dan sel epitel untuk pembentukan cangkang (Addadi et al., 2006 dan Chi-Miau dan Watabe, 1989). Lapisan mutiara berfungsi melindungi 'soft tissue' yang ada di dalam cangkang dari organisme parasit yang melubangi cangkang kerang (Barthelat et al., 2007 dan Chi-Miau \& Watabe, 1989). Lapisan tipis terpisah dari periostrakum dan menghilang ketika lapisan periostrakum menjadi dewasa (Chi-Miau dan Watabe, 1989).

Dengan menggunakan mikroskop stereo didapatkan bahwa lapisan mutiara pada bulan ketiga terlihat telah mengalami pertumbuhan dan telah melapisi inti mutiara walau tidak begitu merata. Pada bulan kesembilan inti mutiara mengalami pertumbuhan ketebalan dan lapisan mutiara terlihat merata melapisi inti mutiara yang ditempelkan. Ukuran tebal lapisan mutiara kerang Pteria penguin yang didapat dari dua mutiara (bulan I dan bulan II) sampai sepuluh mutiara blister (mabé) (bulan kesembilan) dalam satu individu, memiliki rata-rata ketebalan $25.266 \mu \mathrm{m}$ pada bulan ketiga, $46.12 \mu \mathrm{m}$ bulan kelima dan $47.180 \mu \mathrm{m}$ bulan kesembilan. Sedangkan ukuran tebal lapisan 
cangkang kerang $66 \mu \mathrm{m}$ bulan ketiga, $163.9 \mu \mathrm{m}$ bulan kelima dan $71.72 \mu \mathrm{m}$ bulan kesembilan. Perbedaan ketebalan lapisan mutiara dan lapisan cangkang dari setiap satu individu pada bulan ketiga $40.733 \mu \mathrm{m}$, bulan kelima $117.78 \mu \mathrm{m}$ dan bulan kesembilan $24.539 \mu \mathrm{m}$.

Berdasarkan perkembangan blister pada Pteria penguin yang disampling dan diamati bahwa pada bulan kesembilan lapisan mutiara sudah membungkus secara utuh inti mutiara. Waktu antara implementasi inti dan panen mutiara pada umumnya 612 bulan. Ketebalan nakre umumnya dari mutiara mabé antara 0.7-2.5 mm (Shirai, 1981; McLaurin et al., 1997, 1999 dalam Taylor \& Strack, 2008). Penelitian yang dilakukan Ruiz-Rubio et al (2006) produksi mutiara mabé pada kerang Pteria sterna menunjukkan ketebalan lapisan nakre yang dicapai dalam 5 bulan adalah $0.75 \mathrm{~mm}$. Sedangkan, ketebalan blister kerang Pteria penguin yang dilakukan dalam penelitian menunjukkan bahwa pada bulan kelima ukuran ketebalan lapisan mutiara $46.12 \mu \mathrm{m}(0.04612 \mathrm{~mm})$. Dengan demikian, perbandingan ukuran ketebalan antara Pteria penguin dalam penelitian ini dan Pteria sterna adalah $0.70388 \mathrm{~mm}$. Berdasarkan pembentukan lapisan mutiara dalam sembilan bulan perkembangan, lapisan mutiara yang baik digunakan adalah bulan kesembilan dapat dilihat. Hal ini juga dikemukakan Ruiz-Rubio et al (2006), proses panen kerang mutiara yang baik setelah bulan kesembilan.

Hal ini diasumsikan karena kerang yang digunakan sebagai kerang uji berasal dari induk yang berbeda dan memiliki umur yang bervariasi sehingga pada kegiatan monitoring dan sampling pada bulan kesembilan tersebut memiliki umur yang jauh lebih tua dari kerang yang disampling bulan sebelumnya (Saucedo dan Sauthgate, 2008 \& Makhas et al., 2015). Menurut Schone et al. (2005) dalam Makhas et al. (2015) pada saat kerang berumur sudah tua atau kerang yang sudah dewasa akan mengalami kejenuhan dan cenderung bertumbuh lebih lambat dalam melapisi inti sehingga lapisan nakreous tidak banyak. Walaupun faktor lainnya seperti faktor lingkungan juga dipercaya mempengaruhi pertumbuhan kerang mutiara (Lucas, 2008).

\section{KESIMPULAN}

Perbandingan ketebalan lapisan mutiara dan lapisan cangkang selama penelitan adalah $40.733 \mu \mathrm{m}$ pada bulan ketiga, $117.78 \mu \mathrm{m}$ pada bulan kelima dan $24.539 \mu \mathrm{m}$ bulan kesembilan. Ketebalan rata-rata tablet aragonite lapisan mutiara pada bulan ketiga $457.25 \mathrm{~nm}$, bulan kelima $326.75 \mathrm{~nm}$ dan bulan kesembilan $325.75 \mathrm{~nm}$ sedangkan pada lapisan cangkang pada bulan ketiga $483.75 \mathrm{~nm}$, bulan ketiga $424.75 \mathrm{~nm}$ dan bulan kesembilan $333.5 \mathrm{~nm}$.

\section{DAFTAR PUSTAKA}

Addadi, L., D. Joester., F, Nudelman dan S. Weiner. 2006. Mollusk shell formation: a source of new concepts for understanding biomineralization processes. Weizman Institute of Science. Chemistry a european journal 8: 980-987.

Almeida, M.J., J. Machado end J. Coimbra. 1997. Growth and biochemical composition of Crassostrea gigas (Thunberg) at three fishfarm earthen ponds. Journal of Shellfish Research, 16: (2), $455-462$.

Barthelat, F and H.D. Espinosa. 2007. An experimental investigation of deformation and fracture of nakremother of pearl. Experimental Mechanics, 47: 311-324.

Fougerouse, A., M. Rousseau and J.S. Lucas. 2008. Soft tissue anatomy, shell structure and biomineralization (p 77-102). 
Dalam: Southgate P.C and Lucas J.S. The pearls oyster. Elsevier BV, Amsterdam.

Gervis, M.H., and N.A Sims. 1992. The biology and culture of pearl oysters (Bivalvia Pteriidae). International center for living aquatic resources management, manila. p 49.

Hamzah, M. S., dan B. Nababan. 2009. Studi pertumbuhan dan kelansungan hidup anakan kerang mutiara (Pinctada maxima) pada ke dalaman berbeda di Teluk Kapontori, Pulau Buton. E-Jurnal IImu dan Teknologi Kelautan Tropis, 1 (2): 22-32.

Lacoste, E., G. L. Moullac., P. Levy., Y. Gueguen and N. GaertnerMazouni. 2014. Biofouling development and its effect on growth and reproduction of the farmed pearl oyster Pinctada margaritifera.

Makhas, K. A., N. G . F. Mamangkey dan D. M. H. Mantiri. 2014. Analisis struktur bangunan dan senyawa lapisan mutiara jenis mabe pada Pinctada margaritifera.
Jurnal Pesisir dan Laut Tropis, 1 (1): 13-18.

Mamangkey, N. 2009. Improving the quality of pearls from Pinctada maxima. Thesis. James Cook University eprint. p 167.

Ruiz-Rubio, H., H. Acosta-Salmon, A. Olivera, P. C. Southgate and C. Rangel-D ávalos. 2006. The influence of culture method and culture period on quality of halfpearls ('mabé') from the winged pearl oyster Pteria sterna, Gould, 1851. Aquaculture, 254: 269-274.

Strack, E. 2006. Pearls. Stuttgart, Germany: Ruhle-Diebener-Verlag. p 707.

Taylor, J and E. Strack. 2008. Pearl Production (p 273-302). Dalam: Southgate P.C and Lucas J.S. The Pearls Oyster. Elsevier BV, Amsterdam.

Wada, K.T and I Tëmkin. 2008. Taxonomy and phylogeny ( $\mathrm{p}$ 3775). Dalam: Southgate P.C and Lucas J.S. The Pearls Oyster. Elsevier BV, Amsterdam. 